\title{
MAKNA DAN PRAKTIK "SOGOKAN" BAGI WARTAWAN
}

\author{
Wulan Suciska \\ Dosen pada Universitas Negeri Lampung \\ Jl. Sumantri Brojonegoro No.1, Gedong Meneng, Bandar Lampung, 35145 \\ (Makalah diterima tanggal 20 Oktober 2011- Revisi tanggal 4 November 2011)
}

\begin{abstract}
Abstrak
Artikel ini merupakan hasil penelitian yang dilatarbelakangi oleh permasalahan sogokan yang selama ini lebih diidentikkan pada wartawan dari media yang belum mapan. Sedangkan sogokan dalam bentuk amplop ataupun freebies yang terjadi di kalangan wartawan profesional belum terungkap, termasuk maknanya bagi wartawan dan narasumber terkait. Penulis mengintegrasikan teori interaksionisme simbolik dan menggunakan pendekatan subjektifkonstruktivis serta metode penelitian kualitatif dengan tradisi penelitian fenomenologi, atau paradigma interpretif (interpretive paradigm). Hasil penelitian menunjukkan bahwa sogokan menjadi fenomena bukan semata kesalahan wartawan tetapi juga pihak-pihak lain yang berkepentingan dengannya seperti narasumber, pihak media, dan organisasi profesi kewartawanan. Salah satu penyebabnya adalah makna dan batasan pemberian yang termasuk sogokan dengan yang nonsogokan berbeda-beda.
\end{abstract}

Kata Kunci: makna, sogokan, konsep diri, wartawan, teori interaksionisme simbolik

\begin{abstract}
This article is a research result of the inducement problems along this time is identical with the performance of unsettle media journalists. Meanwhile, inducement that happens in the professional press has not reveals yet. This study includes the meaning of inducement that taken by the journalists or sources. The researcher integrates symbolic interactionism theory and constructivist subjective approach and qualitative research method with phenomenology research tradition or interpretive paradigm. The result showed that inducement became a phenomenon which involving many elements not only the journalists but also the others including news resources, media, and press organization. One of the causes is the meaning that is taken and the definition of inducement was different.
\end{abstract}

Keyword: meaning, inducement, self-concept, journalists, symbolic interactionism theory

\section{PENDAHULUAN}

Wartawan menerima uang sudah menjadi salah satu kajian etika jurnalisme di seluruh dunia. Di China, menerima uang juga kerap disebut menerima amplop dan wartawannya pun disebut wartawan amplop (Shanshan You, 2004).

Dalam buku The Bress Check, Upton Sinclair mengkaji etika kantor berita. Dia menceritakan bagaimana orang-orang berita mendapat sogokan untuk memuat suatu berita. Sekarang semua kode etik melarang hadiah dan sogokan tertentu masih ada pihak yang mencoba mendapat dukungan media dengan menyuap melalui hadiah dan bentukbentuk lainnya yang dikenal sebagai junkets (perjalanan dengan biaya ditanggung orang lain yang mungkin mengharapkan imbalan tertentu). Meski freebies juga dilarang, terkadang beberapa organisasi pers tetap menerima junkets dengan alasan anggaran yang terbatas jika harus mengeluarkan biaya untuk me-review informasi (Vivian, 2008: 640-641). Goodwin (1983) mengungkapkan bahwa "Freebies" mengacu pada sesuatu 
yang diberikan kepada wartawan secara gratis. Dalam konteks praktik kewartawanan, freebies termasuk contoh produk gratis, makan gratis, hadiah-hadiah, potongan harga (diskon), tiket menonton film bioskop atau konser musik gratis. Freebies dianggap dapat merusak integritas jurnalisme (Lo \& Wei, 2008: 25).

Di Indonesia, sogokan bagi wartawan lebih banyak dikaitkan dalam bentuk uang yang dikonotasikan dengan 'amplop'. Jarang yang mengaitkannya dengan hadiah gratis (freebies) atau perjalanan gratis (junkets). Wartawan yang melakukan ini disebut "Wartawan Amplop" atau WTS (wartawan tanpa surat kabar), muntaber (muncul tanpa berita), wartawan bodrex, dan lain-lain.

Kode Etik Wartawan Indonesia (KEWI) maupun Kode Etik Jurnalistik (KEJ) belum secara tegas melarang penerimaan sogokan, baik berupa freebies ataupun junkets. Di dalam KEWI pasal 5, hanya mencantumkan kalimat "Wartawan Indonesia tidak menerima suap dan tidak menyalahgunakan profesi". Sedangkan pada pasal 4 KEJ "Wartawan tidak menerima imbalan untuk menyiarkan atau tidak menyiarkan tulisan, gambar, suara atau suara dan gambar yang dapat menguntungkan atau merugikan seseorang atau sesuatu pihak". Ada unsur subjektif dalam kata-kata "yang dapat menguntungkan atau merugikan seseorang atau sesuatu pihak". Artinya, kalau sebuah pemberitaan objektif, tidak masalah menerima imbalan.

Menariknya, budaya amplop selalu dikaitkan dengan wartawan yang berasal dari media yang belum mapan atau wartawan dari media yang tidak jelas eksistensinya. Nurudin (2007: 258) mengungkapkan, 'Wartawan Bodrex' umumnya melanda media massa yang belum mapan dan belum bisa menggaji wartawan dengan memadai.

Di Provinsi Lampung, berdasarkan survei Aliansi Jurnalistik Indonesia (AJI) dan Lampung Media Center (LMC), fenomena sogokan berkaitan dengan minimnya penghasilan yang diperoleh wartawan dari kantor media tempatnya bekerja. Tidak sedikit wartawan yang mengandalkan perolehan upah tambahan itu dari para narasumber dan dari tulisan yang dibuatnya yang "dihargai" oleh pihak yang diuntungkan. (http://bataknews.wordpress.com)

Keputusan wartawan untuk menerima ataupun menolak sogokan terkait dengan bagaimana wartawan memaknai sogokan yang diberikan narasumber.

Penulis mengkhususkan objek penelitian pada wartawan yang berkerja di Kota Bandar Lampung, Provinsi Lampung tepatnya pada surat kabar lokal yang merger dengan surat kabar nasional, yaitu SKHU Lampung Post yang merger dengan Media Indonesia (PT. Surya Pasindo Group) dan SKHU Radar Lampung dari Jawa Post Group, dengan alasan: pertama, kedua surat kabar ini adalah dua pemimpin pasar terbesar di Kota Bandar Lampung. Kedua, kedua SKHU terbesar di Lampung ini dianggap bisa menggaji wartawannya dengan sangat layak sehingga dinilai jauh dari praktik sogokan.

Berdasarkan latar belakang tersebut, maka fokus penelitian sebagai berikut: "Bagaimanakah makna sogokan bagi wartawan SKHU Radar Lampung dan SKHU Lampung Post di Bandar Lampung?".

Penelitian ini bertujuan untuk mengungkap dan menggambarkan:

1. Makna sogokan bagi wartawan surat kabar harian di Bandar Lampung

2. Makna sogokan bagi narasumber, baik dari pihak pemerintah maupun swasta yang berhubungan dengan wartawan surat kabar harian di Bandar Lampung.

3. Bentuk-bentuk dan batasan sogokan yang diterima atau ditolak oleh wartawan surat kabar harian di Bandar Lampung.

\section{METODE PENELITIAN}

Fokus dari penelitian ini adalah mengungkap makna sogokan bagi wartawan surat kabar harian sebagaimana terefleksi dalam pertanyaan penelitian. Metode yang digunakan dalam memperoleh data kualitatif adalah pendekatan subjektif atau interpretif, atau yang disebut Thomas R. Lindlof sebagai paradigma interpretif (interpretive paradigm) (1995: 27). Pendekatan yang dipilih adalah pendekatan atau perspektif subjektif- 
konstruktivis dengan menjelaskan makna perilaku dengan manafsirkan apa yang orang lakukan (Mulyana, 2002: 32). Informan primer dalam penelitian ini adalah 5 wartawan di SKHU Lampung Post dan SKHU Radar Lampung. Ditambah informan sekunder sebagai penguat data yang berasal dari Pemimpin SKHU Radar Lampung dan SKHU Lampung Post, ketua-ketua organisasi profesi wartawan (AJI dan PWI), Pemerintah Provinsi Lampung, humas perusahaan serta pendapat para ahli lainnya yang dianggap perlu di lapangan. Pada teknik pengumpulan data digunakan triangulasi (studi literatur, pengamatan, dan wawancara) untuk meningkatkan kekuatan data, sekaligus mengurangi kelemahan satu teknik pengumpulan data (Patton, 1980). Sedangkan untuk memastikan keabsahan data menggunakan triangulasi dengan sumber yakni membandingkan dan mengecek balik derajat kepercayaan suatu informasi yang diperoleh melalui waktu dan alat yang berbeda dalam metode kualitatif (Patton, 1987 dalam Moleong, 2004: 330-331).

\section{LANDASAN KONSEP}

\section{Makna}

Makna adalah "produk sosial" atau "ciptaan yang dibentuk dalam dan melalui pendefinisian aktivitas manusia ketika mereka berinteraksi" (Blumer, 1969: 4-5). George Herbert Mead, yang dikenal sebagai pencetus awal Teori Interaksi Simbolik menyatakan bahwa orang bertindak berdasarkan makna simbolik yang muncul di dalam sebuah situasi tertentu. Interaksi simbolik didasarkan pada ide-ide mengenai diri dan hubungannya dengan masyarakat, karena ide ini dapat diinterpretasikan secara luas. Ralph LaRossa dan Donald C. Reitzes (1993) memperlihatkan tujuh asumsi dasar Interaksi Simbolik (SI) dalam tiga tema besar (West \& Turner, 2008: 98-104):

a. Pentingnya makna bagi perilaku manusia. LaRossa dan Reitzes menguraikannya dalam tiga asumsi yang diambil dari karya Herbert Blumer (1969) yakni: (1) Manusia bertindak terhadap manusia lainnya berdasarkan makna yang diberikan orang lain pada mereka; (2) Makna diciptakan dalam interaksi antar manusia. Mead menekankan dasar intersubjektif dari makna. Makna dapat ada, menurut Mead, hanya ketika orang-orang memiliki interpretasi yang sama mengenai simbol yang mereka pertukarkan dalam interaksi; (3) Makna dimodifikasi dalam proses interpretif.

b. Pentingnya konsep mengenai diri.

Tema kedua pada SI berfokus pada konsep diri (self-concept), atau seperangkat persepsi yang relatif stabil yang dipercaya orang mengenai dirinya sendiri. SI menggambarkan individu dengan diri yang aktif, didasarkan pada interaksi sosial dengan orang lainnya. Tema ini menambahkan dua asumsi menurut LaRossa dan Reitzes (1993), yakni: (1) Individu-individu mengembangkan konsep diri melalui interaksi dengan orang lain dan (2) Konsep diri memberikan motif untuk perilaku. Proses ini sering kali disebut sebagai prediksi pemenuhan diri (self-fulfilling prophecy), atau pengharapan akan diri yang menyebabkan seseorang untuk berperilaku sedemikian rupa sehingga harapannya terwujud.

c. Hubungan antara individu dengan masyarakat.

Tema ini berkaitan dengan hubungan antara kebebasan individu dengan batasan sosial dengan asumsi: (1) Orang dan kelompok dipengaruhi oleh proses budaya dan sosial, dan (2) Struktur sosial dihasilkan melalui interaksi sosial. Dalam membuat pilihan, individu menunjukkan individualitasnya dan menunjukkan bahwa dia tidak sepenuhnya dibatasi oleh budaya atau situasi.

\section{Wartawan}

Dalam peraturan rumah tangga PWI pasal 9 dan Undang-Undang No. 11/1966 tentang Ketentuan-Ketentuan Pokok Pers, Bab 1, pasal 1, ayat (4) menyebutkan: "Wartawan ialah orang yang melakukan pekerjaan kewartawanan yang berupa 
kegiatan/usaha yang sah berhubungan dengan perkumpulan, pengolahan, dan penyiaran dalam bentuk berita, pendapat, ulasan, gambar-gambar, dan sebagainya dalam bidang komunikasi massa". Dengan demikian, wartawan adalah orang-orang yang melakukan pekerjaan kewartawanan dalam surat kabar, radio, televisi, majalah, internet, maupun kantor berita (Junaedhie, 1991: 277).

Wartawan, menurut Adinegoro, ialah orang yang hidupnya bekerja sebagai anggota redaksi surat kabar, baik yang duduk dalam redaksi dengan bertanggung jawab terhadap isi surat kabar maupun di luar kantor redaksi sebagai koresponden, yang tugasnya mencari berita, menyusunnya, mengirimkannya kepada surat kabar yang dibantunya; baik berhubungan tetap maupun tidak tetap dengan surat kabar yang memberinya nafkah. Singkatnya, ada dua jenis wartawan berdasarkan tugas yang dikerjakan, yaitu reporter dan editor. (Sobur, 2001: 101).

\section{Sumber Berita atau Narasumber}

Ada beberapa jenis sumber berita: pertama, sumber berita berdasarkan sifatnya. Dibagi dalam dua kelompok: sumber berita formal (resmi) dan sumber berita informal (tidak resmi). Sumber berita resmi berasal dari kantor-kantor resmi yang berhubungan dengan masyarakat seperti pusat kegiatan pemerintahan, kantor polisi, dan sebagainya. Sedangkan sumber berita tidak resmi, yaitu berita yang diperoleh dari anggota masyarakat atau tokoh masyarakat, dan sebagainya. adalah orang sebagai narasumber (Sumadiria, 2006: 97-98).

Sumber berita atau narasumber yang dimaksud dalam penelitian ini adalah narasumber resmi yang kerap berhubungan dan berkepentingan dengan wartawan seperti orang-orang dari pemerintahan dan perusahaan.

\section{Sogokan}

Kode Etik Jurnalisme versi Aliansi Jurnalistik Indonesia (AJI) point 14 menegaskan bahwa jurnalis (wartawan) tidak dibenarkan menerima sogokan. Yang dimaksud dengan sogokan adalah semua bentuk pemberian berupa uang, barang dan/ atau fasilitas lain, yang secara langsung atau tidak langsung, dapat memengaruhi jurnalis dalam membuat kerja jurnalistik. Dalam penelitian ini sogokan dibagi dalam dua bentuk umum, yakni: pertama, freebies (hadiah/pemberian gratis), termasuk contohcontoh produk gratis (free samples), makanan gratis (free meals), tiket-tiket konser dan film gratis, dan bahkan biaya perjalanan gratis dengan segala fasilitasnya (junkets). (Goodwin, 1983). Kedua, 'amplop' (sogokan dalam bentuk uang). "Wartawan Amplop" adalah sebutan bagi wartawan yang menerima pemberian uang, baik karena diberi maupun meminta yang berakibat tidak bebasnya menjalankan profesinya secara jujur dan objektif.

\section{Simbol Verbal dan Non Verbal Wartawan}

Membahas makna sogokan bagi wartawan harus dilihat melalui simbol-simbol verbal dan nonverbal yang digunakan oleh para wartawan yang menjadi informan dalam proses komunikasinya. Proses komunikasi mencakup pengiriman pesan dari sistem saraf seseorang kepada sistem saraf orang lain, untuk menghasilkan makna yang serupa dengan yang ada dalam pikiran si pengirim (Tubbs \& Moss, 2005: 72). Pesan verbal melakukan tersebut melalui kata-kata, yang merupakan unsur dasar dari bahasa, dan katakata sudah jelas merupakan simbol verbal. Kata-kata dalam simbol verbal tidak terbatas hanya pada kata-kata yang diucapkan, tetapi juga yang dituliskan (verbal/non vokal) (Tubbs \& Moss, 2005: 112) seperti tulisan wartawan dalam bentuk pemberitaan yang terkait dengan narasumber.

Rakhmat (2001: 83-88) mengartikan simbol sebagai petunjuk, beberapa petunjuk nonverbal yang bisa diamati terkait sogokan antara lain: (1) proksemik-penggunaan jarak dalam menyampaikan pesan (jarak publik, jarak sosial, jarak personal, dan jarak akrab); (2) kinesik-penggunaan gerakan tubuh; (3) fasial/wajah-menunjukkan emosi melalui ekspresi wajah; (4) paralinguistikbagaimana orang mengucapkan lambanglambang verbal seperti tinggi-rendahnya 
suara, tempo bicara, gaya bicara, (5) artifaktual-segala macam penampilan yang diperlihatkan (appearance). Simbol-simbol nonverbal ini akan dilihat dalam proses pengamatan terhadap wartawan yang menjadi informan.

\section{Fenomena Sogokan pada Wartawan di Provinsi Lampung}

Perkembangan pers di Provinsi Lampung, khususnya surat kabar harian sangat pesat. Berdasarkan data Dinas Komunikasi dan Informasi (Diskominfo) Provinsi Lampung, surat kabar harian umum (SKHU) di Provinsi Lampung pada awalnya hanya ada dua surat kabar, yakni $S K H U$ Lampung Post dan SKHU Radar Lampung. Jumlah ini kemudian tumbuh dengan pesat menjadi 8 (delapan) SKHU, di mana 5 (lima) diantaranya adalah jaringan perusahaanperusahaan media nasional, yakni: $S K H U$ Lampung Post milik Media Group; SKHU Radar Lampung, SKHU Rakyat Lampung dan SKHU Trans Lampung milik Jawa Pos Group; dan terakhir SKHU Tribune Lampung miliki Kompas-Gramedia Group.

Semakin banyaknya jumlah SKHU ini, menimbulkan persaingan yang semakin ketat, yang seharusnya diikuti dengan peningkatan kemampuan dan kesejahteraan wartawan, khususnya wartawan di surat kabar harian tersebut. Berdasarkan penelitian yang dilakukan AJI Lampung dan Lampung Media Center (LMC), dalam hal standar upah maupun kesejahteraan, masih banyak wartawan - terutama dari media mingguan-yang harus bekerja keras menutupi biaya operasional dan ongkos cetak medianya, agar sekadar bisa terbit saja. Masih menurut hasil survei AJI Lampung (diperoleh tanggal 29 Januari 2009), secara umum kalau dikategorisasikan, penghasilan wartawan di Lampung dapat dibagi dalam beberapa skala. Wartawan berpenghasilan skala tinggi dengan gaji "take home pay" di atas Rp. 2.000.000/ bulan termasuk fasilitas tambahan lain-lain penghasilan yang sah, bagi koresponden media massa cetak/televisi nasional; dan skala sedang untuk wartawan media harian dan radio mainstream (utama) lokal berpenghasilan Rp. 1.000.000 - Rp.2.000.000/ bulan ditambah fasilitas-fasilitas tertentu; serta skala rendah bagi wartawan media mingguan dan koresponden media nasional yang belum eksis atau kurang aktif menulis (karena penghasilan dinilai dari produktivitas menulis), yaitu antara Rp. 617.500 (Upah Minimum Provinsi/UMP Lampung Rp. 617.000/bulan) hingga Rp. 1.000 .000 sebulan. Tapi adalagi wartawan di Lampung yang berpenghasilan memprihatinkan, di bawah UMP Rp. 617.000/bulan, tanpa fasilitas tambahan apa pun. Berdasarkan penelitian ini, wartawan harian di Lampung yang termasuk berpenghasilan tinggi jika memperoleh penghasilan Rp. 1.650.000/bulan (gaji pokok) belum termasuk fasilitas-fasilitas lainnya.

Minimnya penghasilan yang diperoleh wartawan dari kantor media tempatnya berkerja berkaitan dengan maraknya sogokan. Sejumlah wartawan di Lampung mengaku secara nominal upah atau gaji yang diterima dari medianya setiap bulan tidak cukup untuk membiayai kehidupan mereka sehari-harinya. (http://bataknews.wordpress.com)

Di Lampung diperkirakan ada seribuan orang wartawan, sebagian besar (500-an orang) di antaranya anggota PWI, AJI (65-an), KWRI dan beberapa organisasi pers (belasan wartawan), IJTI (FJTV) sekitar 20an, PRSSNI (penyiar radio) sekitar 50 hingga ratusan wartawan, JRK (penyiar radio komunitas) sekitar 20-an orang, dan mereka yang tidak punya organisasi naungan, sekitar ratusan

(http://www.lampungpost.com) orang.

\section{PEMBAHASAN}

Profesi wartawan adalah profesi yang sangat mengandalkan interaksi dengan pihak lain di sekitarnya. Salah satu tanda dan sekaligus merupakan syarat untuk mampu berinteraksi dengan pihak lain adalah dengan adanya kebutuhan dan kemampuan saling tergantung (interdependensi) antara wartawan dengan narasumber, masyarakat, termasuk pihak media tempatnya berkerja. Salah satu ancaman yang terbesar dalam hubungan profesional antara wartawan dan narasumber 
adalah sogokan. Dalam interaksi di antara sesama wartawan ataupun dengan narasumber, sogokan menjadi simbol atau lambang yang dibangun dengan makna tersendiri. Secara intersubjektif wartawan memiliki lambang "sogokan" yang digunakan untuk berinteraksi di dalam sistem sosial mereka (interaksi simbolik Mead \& Blumer).

Interaksi simbolik pada fenomena sogokan terhadap integritas wartawan di Provinsi Lampung merupakan sebuah kerangka pikir yang dipakai dalam memahami bagaimana wartawan dan orangorang di sekitarnya menciptakan dunia simbolik yang sama mengenai sogokan, membentuk perilaku mereka dan memperlihatkan keterkaitan dan ketergantungan (interdependensi) antara wartawan dengan narasumber dan pihakpihak lainnya (seperti yang diuraikan LaRossa \& Reitzes).

\section{Makna dan Batasan Sogokan}

Untuk bisa melakukan interaksi yang baik berkaitan dengan sogokan, antara wartawan dan narasumber harus bisa menciptakan makna yang sama mengenai sogokan. Tanpa makna yang sama berkomunikasi akan menjadi sangat sulit, atau bahkan tidak mungkin. Makna yang diberikan pada simbol merupakan produk dari interaksi sosial dan menggambarkan kesepakatan untuk menerapkan makna tertentu pada simbol tertentu. Mead menekankan dasar intersubjektif dari makna. Makna dapat ada, menurut Mead, hanya ketika orang-orang memiliki interpretasi yang sama mengenai simbol yang mereka pertukarkan dalam interaksi. Sedangkan Blumer menyatakan bahwa proses interpretif memiliki dua langkah. Pertama, para pelaku menentukan benda-benda yang mempunyai makna. Kedua, melibatkan pelaku untuk memilih, mengecek dan melakukan transformasi makna di dalam konteks di mana mereka berada.

\section{Makna dan Batasan Sogokan Menurut Wartawan}

Semua wartawan yang menjadi informan primer berpandangan bahwa tidak semua pemberian dikategorikan sogokan, ada pemberian yang bukan sogokan. Batasanbatasan pemberian yang masuk dalam kategori sogokan antara lain: (a) Kesepakatan (deal), setelah melalui proses tawar-menawar antara pihak pemberi sogokan (narasumber) dengan pihak yang menerima sogokan (pihak media termasuk wartawan/redaktur/pemimpin redaksi, dst; (b). Didasari atas kepentingan masing-masing pihak yang bersepakat, bukan kepentingan masyarakat akan informasi.; (c) Nominal uang atau nilai barang yang tinggi atau mewah menurut wartawan; (d) Memengaruhi pemberitaan (memperhalus, menerbitkan, atau tidak menerbitkan berita).

Sedangkan batasan-batasan pemberian yang dikategorikan sebagai pemberian nonsogokan, yakni: (a) Kedekatan, hubungan yang muncul antara wartawan-narasumber (b) Nominal uang atau nilai barang yang rendah atau terjangkau bagi wartawan; (c) Tidak memengaruhi pemberitaan, kalaupun ada pengaruhnya, asalkan tidak besar dan tidak diketahui oleh pihak penerbitan; (d) Bukan atas permintaan wartawan; (e) Tujuannya untuk menjalin atau menjaga hubungan.

Setidaknya ada empat indikator yang membedakan makna dan batasan sogokan dan nonsogokan berdasarkan sudut pandang wartawan, yakni: konteks hubungan, kesepakatan (deal) antara kedua belah pihak, nominal uang atau nilai barang dan fasilitas, terakhir pemberitaan.

Sogokan diartikan sebagai semua pemberian baik berupa uang, barang, atau fasilitas dari narasumber kepada wartawan dengan nilai mewah atau di atas rata-rata dan mengandung unsur kesepakatan (deal) antara kedua pihak terkait dengan pemberitaan. Sebaliknya, pemberian nonsogokan adalah semua pemberian baik berupa uang, barang, atau fasilitas yang tidak mahal dalam konteks kedekatan hubungan personal tanpa unsur kesepakatan yang bisa memengaruhi pemberitaan. 
Tabel 1

Perbedaan Sogokan dan Non Sogokan

\begin{tabular}{|c|c|c|c|}
\hline No. & Indikator & Sogokan & Non Sogokan \\
\hline 1. & Konteks hubungan & $\begin{array}{c}\text { Profesional (wartawan- } \\
\text { narasumber) }\end{array}$ & $\begin{array}{c}\text { Kedekatan (pertemanan, } \\
\text { kekeluargaan) }\end{array}$ \\
\hline 2. & Kesepakatan (deal) dua belah pihak & Ada & Tidak ada \\
\hline 3. & $\begin{array}{c}\text { Nominal uang atau nilai barang dan } \\
\text { fasilitas }\end{array}$ & Besar, mewah & $\begin{array}{c}\text { Standar, murah, cenderung } \\
\text { rendah dan masih mampu } \\
\text { dibiayai sendiri oleh wartawan }\end{array}$ \\
\hline 4 & Pemberitaan & $\begin{array}{c}\text { Memengaruhi pemberitaan } \\
\text { (memperhalus, tidak } \\
\text { menerbitkan, atau menerbitkan } \\
\text { berita) }\end{array}$ & $\begin{array}{c}\text { Tidak mempengaruhi berita } \\
\text { (tidak ada konsekuensi apa-apa) }\end{array}$ \\
\hline
\end{tabular}

Sumber : Hasil Penelitian 2009

\section{Makna dan Batasan Sogokan Menurut Narasumber}

Sogokan, bagi narasumber yang menjadi informan sekunder ini adalah pemberian kepada wartawan untuk memperlancar kepentingan narasumber. Sogokan lebih mengandung tujuan yang negatif dan culas. Salah satunya adalah kepentingan untuk menutupi atau tidak memublikasikan suatu permasalahan yang bisa membuat citra lembaga atau diri mereka menjadi negatif. Sedangkan pemberian nonsogokan diartikan sebagai pemberian yang diberikan oleh narasumber bertujuan membangun kedekatan dan menjalin hubungan baik yang diistilahkan sebagai "pendekatan". Kedekatan ini diharapkan bisa memberikan keuntungan bagi kedua pihak. Pemberian nonsogokan dianggap tidak memiliki kesepakatan atau konsekuensi apapun pada wartawan yang menerimanya.

Bagi narasumber, ada anggapan pemberian ini sebagai balas jasa atas kesediaan wartawan melakukan wawancara dengan narasumber. Tetapi, ada pula yang menafsirkannya sebagai suap kepada wartawan agar beritanya benar-benar dimuat dan berita itu memuat hal-hal yang baik-baik saja tentang narasumber (Kusumaningrat \& Kusumaningrat, 2006: 100). Meski menyangkal sebagai sogokan, pemberian tersebut mengandung tujuan membangun kedekatan dengan wartawan dan ketika berita yang terbit tidak sesuai dengan keinginan narasumber, narasumber mempertanyakan dan mengajukan keberatan kepada pihak media.

\section{Makna dan Batasan Sogokan Menurut Pemimpin Media}

Bagi pemimpin media, pemberian yang dikategorikan sebagai sogokan batasan utamanya adalah pemberian itu bertujuan untuk memengaruhi pemberitaan. Upaya memengaruhi pemberitaan tersebut mengandung unsur janji-janji yang disepakati antara narasumber yang sedang dalam kondisi terdesak yang memberikan sogokan dengan wartawan yang menerima sogokan untuk memperhalus, menerbitkan berita ataupun tidak menerbitkan berita. Selain itu, batasan pemberian yang termasuk sogokan dilihat dari nominal uang atau nilai barang serta fasilitas yang berlebihan atau tidak wajar. Pemberian yang berlebihan, dikhawatirkan akan memengaruhi independensi wartawan yang menerima sogokan dalam melaksanakan fungsi kontrol sosialnya. Oleh karena itu, wartawan juga harus pandai melihat keterkaitan pemberian dengan peristiwa yang melatarbelakangi pemberian tersebut.

Bagi para pemimpin media, pemberian nonsogokan adalah pemberian yang boleh 
diterima, namun sangat disarankan untuk dihindari. Muncul beberapa istilah khusus pada pemberian nonsogokan, yakni pertama, istilah "makruh", dengan alasan pemberian tersebut bisa ditolak atau dialihkan menjadi pemasangan iklan demi menjaga independensi wartawan. Kalaupun wartawan memutuskan menerimanya, pihak media memakluminya. Kedua, istilah "penjinakan", dengan lebih melihat pada tujuan atau harapan narasumber yang melakukan pemberian kepada wartawan supaya tidak melakukan tindakan yang bisa merusak hubungan kedekatan kedua belah pihak termasuk membuat wartawan tidak kritis.

Terkadang, dengan tekanan untuk menjalin ataupun menjaga hubungan dengan narasumber, wartawan tidak bisa mengelak dari menerima pemberian. Hal ini masih diperbolehkan namun dengan batasan bahwa freebies tersebut bukanlah barang yang mewah, dengan tolok ukur nilai barang tersebut masih bisa dibeli sendiri oleh wartawan. Selain itu, freebies yang diterima adalah pemberian yang diberikan bukanlah pemberian yang dikhususkan pada satu wartawan melainkan diberikan pula pada pihak-pihak lain yang berada dalam konteks yang sama.

Berdasarkan wawancara dengan para pemimpin media ini diperoleh sikap-sikap yang diambil para pemimpin media bagi SKHU yang dipimpinnya dalam menyikapi fenomena sogokan yang terjadi pada wartawannya, yakni:

a. Sikap Terhadap Sogokan dan Nonsogokan

- Larangan, sogokan dalam bentuk uang dan freebies dilarang jika ada indikasi sudah berlebihan. Sogokan yang sangat dilarang dan diharamkan dalam bentuk uang yang kerap disebut "amplop" dari hasil memeras narasumber termasuk pemberian uang sebagai reward atas penulisan yang positif mengenai narasumber.

- Diperbolehkan. Pemberian yang diperbolehkan adalah pemberian-pemberian yang jika dihindari justru akan menghambat pelaksanaan tugas jurnalistik. Salah satunya karena pemberian tersebut merupakan bagian dari aturan peliputan atau menjadi satusatunya jalan bagi wartawan untuk memperoleh berita.

b.Sosialisasi Aturan. Kedua SKHU mengaku bahwa sosialisasi aturan termasuk di dalamnya penerapan kode etik jurnalistik yang tegas, kepada wartawan telah diberikan mulai dari proses recruitment wartawan.

c.Pengawasan. Pengawasan pertama, dengan mengevaluasi setiap berita dan setiap halaman. Menariknya, semua pemimpin media mengaku bisa membedakan mana berita yang mengandung nilai sogokan dengan yang tidak mengandung nilai sogokan hanya dengan membacanya. Kedua, melalui rapat-rapat. Setiap harinya minimal diadakan dua kali rapat yang berkaitan dengan berita, yakni rapat proyeksi yang dilaksanakan di pagi hari dengan agenda pembagian tugas liputan, dan rapat budget yang dilakukan sore hari untuk mengevaluasi berita-berita yang diperoleh. Pada kedua rapat ini, biasanya para staff redaksi saling mengkritisi setiap berita yang dianggap ada kejanggalan. Ketiga, dilakukan dengan meminta bantuan informasi atau laporan yang dapat dipertanggungjawabkan dari pihak luar atau masyarakat.

d.Sanksi. Setelah bukti-bukti pelanggaran yang dilakukan wartawan dirasakan cukup, maka pihak media akan memberikan sanksi, sesuai pelanggaran yang dilakukan. Pada SKHU Lampung Post, sanksi yang berlaku dilakukan dengan beberapa tahapan, mulai dari teguran, peringatan tertulis, sampai pemecatan. Pada SKHU Radar Lampung, sanksi yang diberlakukan adalah memberikan peringatan, penurunan pangkat, hingga pemecatan. Kecuali untuk tindakan pemerasan kedua SKHU langsung memberikan sanksi pemecatan.

\section{Makna dan Batasan Sogokan Menurut Organisasi Profesi Wartawan}

Aliansi Jurnalis Independen (AJI) dan Persatuan Wartawan Indonesia (PWI) adalah 
dua bentuk organisasi kewartawan yang selama ini menjadi organisasi yang dipilih oleh para wartawan/jurnalis Indonesia, dari berbagai bentuk media termasuk di Provinsi Lampung. Kode Etik Jurnalistik versi AJI maupun versi PWI secara jelas telah mengungkapkan bahwa sogokan atau suap adalah semua bentuk pemberian, baik dalam bentuk uang, barang, ataupun fasilitas dari pihak lain yang secara langsung maupun tidak langsung dianggap memengaruhi independensi wartawan dalam melakukan tugas-tugas jurnalistiknya. Namun, pada praktiknya, kedua organisasi profesi ini membedakan pemberian yang tidak boleh diterima sama sekali dan pemberian yang masih bisa boleh diterima wartawan dalam pelaksanaan tugasnya.

Kedua organisasi profesi wartawan ini bersepakat, bahwa pemberian dalam bentuk uang sama sekali tidak diperbolehkan untuk diterima wartawan. Tanpa melihat nominal, atau besar-kecilnya nilai, semua pemberian uang dari pihak lain atau narasumber kepada wartawan harus ditolak. Pemberian uang secara jelas dan tegas menunjukkan adanya upaya narasumber memengaruhi pihak penerima uang terkait dengan profesi kewartawanannya. Jika bukan karena profesi wartawan yang memiliki akses pada pemberitaan, tidak ada pihak lain yang akan memberi uang secara cuma-cuma.

Menariknya, pelarangan secara tegas tidak diterapkan pada pemberian dalam bentuk barang dan fasilitas-fasilitas dari narasumber atau pihak lain kepada wartawan. Bagi AJI, harus ada tolak ukur yang memandu wartawan memahami standar yang jelas pemberian barang atau fasilitas apa yang masih boleh diterima dengan pemberian yang tidak boleh diterima oleh mereka. Tanpa standar tolak ukur yang jelas, wartawan akan mengalami kebingungan dalam menyikapi pemberian. Hanya saja, yang harus diutamakan oleh para wartawan dalam melihat pemberian bukanlah nominal pemberian tersebut melainkan independensi wartawan dalam pelaksanaan tugas jurnalistiknya, apabila dirasakan akan memengaruhi independensinya, sebaliknya wartawan berani untuk menolaknya.
Secara garis besar bisa disimpulkan, baik AJI maupun PWI melihat pemberian yang diberikan narasumber kepada wartawan dalam bentuk apapun, dari siapapun, dan untuk apapun sebaiknya ditolak oleh wartawan. Terutama pemberian dalam bentuk uang. Kecuali pemberian tersebut menjadi satu-satunya cara untuk mendapatkan berita. Hal ini dalam upaya untuk tetap menjaga independensi wartawan dalam melaksanakan tugasnya.

\section{Bentuk-bentuk Pemberian Pada Wartawan}

Profesi wartawan adalah profesi yang sebenarnya memang tidak akan lepas dari kepentingan. Yang bisa dilakukan adalah menekannya, sebab, tidak ada ukuran pasti seberapa jauh kepentingan itu tidak boleh terlibat dalam profesi wartawan. Ada beberapa bentuk pemberian yang kerap ditawarkan atau diterima oleh wartawan, sebagai berikut:

1. Uang. Pemberian dalam bentuk uang ini sangat bervariasi. Mulai dari nominal, tujuan, sampai cara pemberian. Ada pemberian uang secara langsung dan dimasukkan ke amplop, ada pula yang melalui rekening wartawan. Berikut beberapa pemberian uang yang dibedakan secara langsung berdasarkan tujuan atau alasannya: (a) Imbalan (Reward) Penulisan; (b) Uang liputan; Uang Kedekatan Hubungan disebut "cash"; (c) Tunjangan Hari Raya (THR); (d) Uang Kesepakatan (deal) yang biasanya memengaruhi pemberitaan; dan (e) Honor bulanan, seperti gaji tetap dari perusahaan atau beat tempat wartawan melakukan liputan secara regular.

2. Perjalanan Gratis (akomodasi, transportasi, uang saku,dll). Perjalanan yang diatur oleh perusahaan biasanya dalam bentuk media gathering, di mana beberapa wartawan perwakilan dari media massa yang berbeda diundang untuk menghadiri acara yang diadakan perusahaan. Tujuannya, mendekatkan hubungan antara pihak media dan perusahaan. Sedangkan perjalanan yang diberikan oleh pemerintah kepada wartawan ke luar 
daerah, luar kota, atau luar negeri dengan tujuan untuk membuat liputan kunjungan kerja atau pelesiran ke luar negeri.

3. Voucher: Voucher umumnya adalah kartu atau kertas yang bisa ditukarkan dengan barang-barang tertentu atau pelayanan tertentu (Oxford Learner's Pocket Dictionary, 2002: 462). Pada voucher biasanya tertera nominal tertentu pengganti uang yang bisa ditukarkan dengan barang atau pelayanan tertentu yang bernilai sama dengan nominal tersebut. Ada dua macam voucher yang kerap diterima oleh wartawan terutama wartawan beat, yakni: Voucher belanja dan Voucher pulsa telepon.

4. Makan-makan Gratis. Pemberian makanmakan gratis termasuk pemberian yang paling sering diterima wartawan. Meski wujudnya sama, informan memaknai makan-makan ke dalam beberapa kategori, yakni: (a) Jamuan acara, sifatnya lebih formal; (b) Pemberian informasi, sifatnya informal; (c) Pendekatan, upaya narasumber untuk membangun kedekatan dengan wartawan agar bisa memengaruhi pemberitaan.

5. Cindera mata (Souvenir). Freebies yang diberikan bentuknya produk-produk promosi atau oleh-oleh perjalanan.

6. Barang-barang Penunjang Penampilan. Freebies jenis ini berupa barang yang digunakan sehari-hari oleh wartawan.

7. Proyek Pembangunan. Dari pengakuan salah seorang pemimpin media terungkap bahwa, beberapa surat kabar didirikan dengan tujuan untuk mendapatkan proyek pembangunan dari narasumber. Caranya dengan memberitakan hal-hal negatif dan menyudutkan terkait dengan narasumber tersebut. Baik secara pribadi maupun institusi yang dipimpinnya secara terusmenerus agar narasumber merasa terusik. Setelahnya diharapkan narasumber tersebut akan melakukan negosiasi dengan pihak media pengejar proyek untuk tidak lagi memberitakan dan salah satu kompensasinya adalah proyek pembangunan.
8. Parcel. Gratifikasi dalam bentuk parcel ini ternyata masih berlangsung dan masih diperbolehkan untuk diterima.

9. Iklan. Iklan dijadikan alat untuk membungkam media, termasuk wartawan agar tidak memberitakan hal-hal yang negatif tentang diri pemasang iklan.

10. Tanah. Pemberian ini merupakan kehendak wartawan atas hasil kesepakatan (deal) dengan narasumber yang berkaitan dengan pemberitaan serta mengandung unsur pemerasan. Hal ini terungkap dari pengalaman rekan informan primer yang diceritakan kepada dirinya.

\section{Praktik-praktik Sogokan}

Berdasarkan wawancara dengan para informan primer maupun informan sekunder, ada beberapa pola-pola praktik sogokan yang terjadi dalam pelaksanaan tugas-tugas jurnalistik wartawan.

1. Sogokan atas Inisiatif Wartawan, ada beberapa bentuk praktik, yakni: a) Mengarahkan dan memanfaatkan berita untuk memperoleh iklan, b) Mengarahkan dan memanfaatkan berita agar bisa bernegosiasi dengan narasumber, c) Mengancam dan memeras narasumber dengan berita, d) Meminta fasilitas, uang, dan/atau barang dengan atau tanpa berkaitan dengan berita, e) Menjual berita pengganti iklan, dengan membuat harga pada berita yang mereka buat dengan ukuran iklan.

2. Sogokan atas inisiatif Narasumber, yakni : a) Mengikat wartawan dengan uang, fasilitas, dan atau barang agar merasa dekat dan "jinak", b) Memasang iklan, c) Membayar berita, biasanya dilakukan narasumber yang merasa memiliki kesalahan-kesalahan, aib, atau kasus yang harus ditutup-tutupi.

Tentu saja tidak semua konsep yang disebutkan dalam penelitian ini merupakan penggambaran seluruh fenomena sogokan terhadap wartawan yang terjadi di Kota Bandar Lampung. 


\section{Gambar 1}

\section{Konsep Diri Wartawan terhadap Integritas Dirinya}

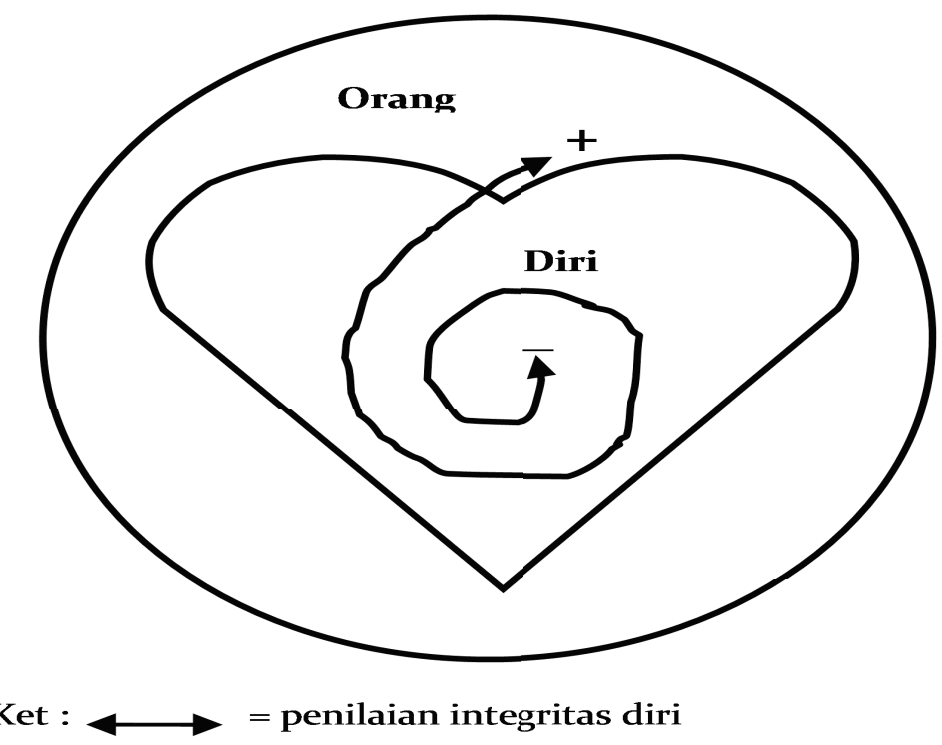

Sumber: Diadaptasi dari Integrating Model of Organizing (Kreps, 1986: 25)

\section{Konsep Diri Wartawan}

Tema kedua pada SI berfokus pada konsep diri (self-concept), atau seperangkat persepsi yang relatif stabil yang dipercaya orang mengenai dirinya sendiri. SI menggambarkan individu dengan diri yang aktif, didasarkan pada interaksi sosial dengan orang lainnya. Tema ini menambahkan dua asumsi menurut LaRossa dan Reitzes (1993), yakni: 1) Individu-individu mengembangkan konsep diri melalui interaksi dengan orang lain dan 2) Konsep diri memberikan motif untuk perilaku. Pemikiran bahwa keyakinan, nilai, perasaan, penilaian mengenai diri memengaruhi perilaku adalah sebuah prinsip penting dalam SI.

Berdasarkan hasil wawancara, konsep diri wartawan yang dinilai dari integritas mereka sebagai wartawan profesional tergantung dari sudut pandang mana konsep diri tersebut dinilai. Seperti dalam gambar 1.

Dari gambar 1 terlihat ketika menilai diri sendiri, para wartawan yang menjadi informan lebih banyak yang bersikap jujur bahwa konsep diri mereka negatif atau tidak terlalu baik. Tindakan mereka menerima sogokan masih dinilai sebagai tindakan yang buruk, meskipun informan beralasan bahwa tindakan menerima sogokan adalah tindakan yang masih manusiawi dilakukan ditengah kebutuhan-kebutuhan hidupnya. Sebaliknya, ketika diminta menilai konsep diri mereka dari sudut pandang orang lain, mereka merasa penilaian orang terhadap konsep dirinya masih positif. Informan merasa meski menerima pemberian dari narasumber, integritasnya sebagai wartawan masih terjaga.

\section{KESIMPULAN}

Makna sogokan memengaruhi interaksi wartawan. Secara intersubjektif wartawan memiliki lambang "sogokan" yang digunakan untuk berinteraksi di dalam sistem sosial mereka. Fenomena sogokan terbentuk atas adanya pertukaran ide, simbol, makna dan hubungan antara wartawan dengan pihakpihak lainnya. Ada pemberian yang bukan sogokan dan masih boleh diterima. Hanya saja, makna batasan-batasan antara sogokan dan bukan sogokan antara wartawan, narasumber, pemimpin media dan organisasi profesi kewartawanan berbeda-beda. Beberapa bentuk pemberian yang kerap 
ditawarkan atau diterima oleh wartawan, yakni: uang, perjalanan gratis dengan fasilitas lengkap, voucher belanja, dan voucher pulsa telepon, makan-makan gratis, cindera mata (souvenir), barang-barang Penunjang Penampilan, Proyek Pembangunan; (8) Parcel; (9) Iklan; dan (10) Tanah. Wartawan yang menjadi informan lebih banyak yang bersikap jujur bahwa konsep diri mereka negatif atau tidak terlalu baik. Tindakan mereka menerima sogokan dinilai sebagai tindakan yang buruk, meskipun informan beralasan bahwa tindakan menerima sogokan adalah tindakan yang manusiawi dilakukan ditengah kebutuhankebutuhan hidupnya. Sebaliknya, ketika diminta menilai konsep diri mereka dari sudut pandang orang lain, mereka merasa penilaian orang terhadap konsep dirinya masih positif .

Berdasarkan kesimpulan tersebut maka penulis menyarankan: pihak media hendaknya memberikan kesejahteraan kepada para wartawannya sehingga wartawan tidak akan berani menerima sogokan.

Pihak media dan organisasi kewartawanan perlu memberikan pemahaman tentang kode etik jurnalistik serta tugas, pokok dan fungsi wartawan.

\section{DAFTAR PUSTAKA}

\section{Buku:}

Day, Louis A. 1991. Ethics in Media Communications: Cases and Controversies. Belmont California : Wadsworth Publishing Company.

Kreps, Gary L. 1986. Organizational Communication Theories and Practices. New York \& London: Longman.

Moleong, Lexy J. 2004. Metode Penelitian Kualitatif edisi revisi. Bandung : Remaja Rosdakarya.

Nurudin. 2007. Pengantar Komunikasi Massa. Jakarta : Rajawali Pers.
Rakhmat, Jalaluddin. 2001. Psikologi Komunikasi, edisi revisi. Bandung : Remaja Rosdakarya.

Sobur, Alex. 2001. Etika Pers (Profesionalisme dengan Nurani). Bandung : Humaniora Utama Press.

Sumadiria, AS Haris. 2006. Jurnalistik Indonesia (Menulis Berita dan Feature Panduan Praktis Jurnalis Profesional). Bandung : Simbiosa Rekatama Media.

Tubbs, Stewart L., \& Moss, Sylivia. 2005. Human Communication: PrinsipPrinsip Dasar. Terjemahan Deddy Mulyana. Bandung : Remaja Rosdakarya.

Vivian, John. 2008. Teori Komunikasi Massa, edisi kedelapan. Jakarta : Kencana Prenada Media Group.

West, Richard \& Turner, Lynn H. 2008. Pengantar Teori Komunikasi (Analisis dan Aplikasi) Buku 1. Jakarta : Salemba Humanika.

\section{Sumber Lainnya: \\ Internet :}

Lo, Ven Hwei., \& Wei, Ran. 2008. Ethical Risk Perception of Freebies and Effect on Journalists Ethical Reasonings. Chinese Journal of Communication Vol. 1, No. 1, April 2008, halaman 25-37. Diakses melalui (http://pdfserve.informaworld.com/4871 65_79145577.pdf) pada tanggal $27 / 10 / 2008$.

You, Shanshan. 2004. Envelope Journalisme In China. Tesis. California State University, Fresno. Diakses melalui (http://www.csufresno.edu/gradstudies/t hesis/Fall2004pdf.pdf) pada tanggal 24/10/2008.

http://lampungpost.com 